\title{
ZEOLITE USAGE FOR INTERVENTIONS IN ACCIDENTAL POLUTIONS BY MINE WATERS IN MARAMUREŞ COUNTY
}

\author{
Bianca BUZ ${ }^{2}$, A. FEKETE ${ }^{2}$, S. NACU ${ }^{1}$
}

\begin{abstract}
This study presents the results obtained using natural zeolites for retaining heavy metals from the Maramureş rivers affected by the mining activities. Natural zeolites from the north-west Transsylvania have been tested, i.e. zeolite from Călineşti-Maramureş and two sorts of zeolites manufactured by SC Zeolitos SRL Oradea. Natural zeolites represint a technical and economical alternative to ion-exchange synthetic resins and classical waste water technologies. Heavy-metal containing wates from Cisla, Burloaia, Cavnic, Săsar, Buşag and Ilba rivers have been used. Metal concentrations of untreated vs. treated samples have been determined for the zeolites containing clinoptilolite. The adsorbtion of metals ( $\mathrm{Mn}, \mathrm{Cu}, \mathrm{Zn}$ ) during a 24h period has been studied for various zeolites.
\end{abstract}

Keywords: zeolite, clinoptilolite, mine waters,heavy metals, manganese, copper.

\section{INTRODUCTION}

Zeolites have been discovered in 1857 by Cronsted, a Swedish mineralogist, who reported the first natural zeolite, stilbite .

Various researchers study the zeolites during $1777-1800$ period, and in 1862 St Claire Devile obtains levynite, the first synthetic zeolite [1]. Clinoptilolite, the main zeolite used in determinations, has long been considered as a variety of heulandite, but due to its structural properties has finally been proved to be a material of its own.

The ideal chemical composition of clinoptilolite is denoted as $(\mathrm{NaK})_{4} \mathrm{CaAl}_{6} \mathrm{Si}_{30} \mathrm{O}_{72} \cdot 24 \mathrm{H}_{2} \mathrm{O}$. Si/Al ratio is 2.7 for heulandite and from 4 to 5.3 for clinoptilolite [2]. Potassium and hydrogen based clinoptilolite is stable up to $800^{\circ} \mathrm{C}$, while calcium based heulandite degrades at $500-550^{\circ} \mathrm{C}$ [3].

Natural as well as synthetic zeolites continue to have various industrial applications. In the last decades natural zeolites have been used in environment protection and for biopharmaceutical applications.

Mabel Vaca Mier and coworkers have studied the ion exchange interactions of $\mathrm{Pb}(\mathrm{II}), \mathrm{Cd}(\mathrm{II})$ and $\mathrm{Cr}(\mathrm{VI})$ on natural clinoptilolite support [4]. Erden E. et. al. have studied the $\mathrm{Co}(\mathrm{II}), \mathrm{Cu}(\mathrm{II}), \mathrm{Zn}(\mathrm{II})$ and $\mathrm{Mn}(\mathrm{II})$ adsorbtion on natural zeolites (clinoptilolite) [6]. Zeolites have attracted the interest of scientists for various environmental applications [7]. Kedziora and coworkers reviewed the

1 National Administration"Apele Românei", 0100180 Bucharest, Romania, e-mail: simion.nacu@rowater.ro

2 Water Basin Administration"Someş-Tisa", 400213 Cluj-Napoca, Romania, e-mail: bianca.buz@dast.rowater.ro, alexandru.fekete@dast.rowater.ro 
literature on zeolites and modified zeolites usage in environmental engineering for water purification and waste water treatment regarding inorganic and organic pollutants [8]. Zeolites as cheap adsorbants can be used for aquatic environment protection against detergents [9]. Studies on natural zeolites such as clinoptilolite and chabazite revealed an increased affinity for retaining arsenic both as arsenite or arsenate [10]. Research on the structure of Romanian zeolites have been carried out by Mocanu and coworkers [3, 11] and Neagoe and coworkers [9]. Smical et. al. have studied the adsorbtion of $\mathrm{Pb}(\mathrm{II})$, $\mathrm{Cu}$ (II) and $\mathrm{Zn}$ (II) on volcano zeolite tuffs from Maramureş [13].

Cătuneanu et. al. have used natural zeolites as filter layer for the recycling of industrial waste waters containing heavy metals [14].

Mozgawa and coworkers have studied various zeolite structures employing FT-IR technique [15]. Ruggieri and coworkers have studied arsenic retention from water on various zeolite supports [16].

Yorukoglu has studied the possible usage of clinoptilolite for retaining ammonia and heavy metals such as $\mathrm{Pb}$ (II), $\mathrm{Cu}$ (II), $\mathrm{Cd}$ (II) şi $\mathrm{Zn}$ (II) from water [17]. Elizabeth Von-Kiti obtained synthetic zeolites which were then tested for desalination of the sea water [18]. Inglezakis and coworkers have studied the adsorbtion efficiency of the pretreated clinoptilolite [19]. Cerjan-Stefanovicand coworkers have studied the influence of the natural zeolite pretreatment on the retention of $\mathrm{Zn}(\mathrm{II})$ and $\mathrm{Mn}$ (II) ions [20]. Wang and Peng have studied natural zeolites for water treatment [21]. Eyde has studied the usage of zeolite for heavy metals recovery from mine waters [22]. Cincotti and coworkers have studied ammonia and heavy metal retention by the natural clinoptilolite from Sardinia [23]. Woinarski and coworkers have studied the adsorbtion of copper ions on natural zeolites at low temperatures [24].

The goal of this research is to find cheap and efficient solutions for interventions in accidental pollution with mine waters containing heavy metals. The waters of the Maramureş county are still containing heavy metals. Due to inneficient strategies related to the mine closures the existing mine waste waters stations do not always ensure total purification of the mine waters so that the rivers in Maramureş county have a significant load of heavy metals.

\section{EXPERIMENTAL SECTION}

Experimental part has been undertaken in the Regional Laboratory for Water Quality Cluj, part of Someş-Tisa Water Administration.

The laboratory is accredited by Renar SR EN ISO/CEI 17025-2005 with the credential certificate LI 491. The heavy metal determinations have been performed on a Agilent Technologies 7500cx ICP-MS, according to the SR EN ISO 17294-1 and SR EN ISO 17294-2 standards.

Water samples containing heavy metals from former mining areas of Maramureş county have been tested. Samples have been taken from Baia Borşa 
(Burloaia mixture), Cavnic river at Cavnic, Săsar river at Baia Mare, Ilba river at Ilba and Nistru river at Buşag. The adsorbing materials tested are the zeolite from Călineşti coded ZV, grained zeolite sort $1(1-2 \mathrm{~mm})$, produced by SC Zeolitos SRL coded ZS1, zeolite sort 2 (2-5 mm), produced by SC Zeolitos SRL coded as ZS2 and perlite coded as ZN. To name the samples we use two codes: zeolite type - mine water and zeolite - regeneration acid - mine water. To designate zeolites regenerated with $\mathrm{HCl}$ we use a $\mathrm{C}$ index and for those regenerated with $\mathrm{HNO}_{3}$ we use $\mathrm{N}$. The naming of the mine waters is the following: $\mathrm{MB}$ - Burloaia mixture, $\mathrm{C}$ - Cavnic, $\mathrm{B}$ Nistru, S - Săsar and I - Ilba. All of the absorbing materials have been prewashed with large amount of double distilled water, to avoid the liberation of the metals from the zeolite structures.

\section{RESULTS AND DISCUSSION}

Green zeolite $(\mathrm{ZG})$ from Călineşti-Maramureş and two sorts of grained zeolite: 1-2 $\mathrm{mm}$ (Z-S1) and 2-5 mm (Z-S2) have been used for the determination of metal retention by the waters from Cisla, Cavnic, Nistru, Săsar and Ilba rivers. The behavior of the zeolites activated with hydrochloric acid (-C-) and nitric acid (-N-) has also been tested.

Mineral composition of the two sorts of grained zeolites is presented in table 1 and the chemical composition in table 2 [25].

Table 1. Mineral composition of the zeolite. Table 2.Chemical composition.

\begin{tabular}{|l|l|}
\hline Composition & Percentage \% \\
\hline Clinoptilolite & $60-70$ \\
\hline Quartze & $4-8$ \\
\hline Biotit & $10-14$ \\
\hline Feldspar & $6-10$ \\
\hline Calcite & $3-5$ \\
\hline
\end{tabular}

\begin{tabular}{|l|l|}
\hline Oxide & Percentage \% \\
\hline $\mathrm{SiO}_{2}$ & $60-70$ \\
\hline $\mathrm{Al}_{2} \mathrm{O}_{3}$ & $5.0-9.0$ \\
\hline $\mathrm{Fe}_{2} \mathrm{O}_{3}$ & $0.5-1.8$ \\
\hline $\mathrm{CaO}$ & $4.5-10$ \\
\hline $\mathrm{MgO}$ & $0.5-1.2$ \\
\hline $\mathrm{K}_{2} \mathrm{O}$ & $2.0-6.0$ \\
\hline $\mathrm{Na}_{2} \mathrm{O}$ & $0.1-0.8$ \\
\hline $\mathrm{TiO}_{2}$ & $0.01-0.06$ \\
\hline $\mathrm{MnO}$ & $0.06-0.1$ \\
\hline
\end{tabular}

A decrease of the heavy metal concentration is noticed as compared to the blank on various zolites or perlite. No significat difference is noticed regarding the behavior of the untreated zeolite vs. zeolite activated with with mineral acids ( $\mathrm{HCl}$ and $\mathrm{HNO}_{3}$ ) when tested with mine water from Burloaia mine so that the determination on the waters from Cavnic, Ilba, Nistru and Săsar river have only been performed on the untreated zeolites.

The variation of the manganese concentration from mine waters of rivers is presented in ( Fig. 1). The variation of the copper concentration from mine waters of rivers is presented in ( Fig. 2). 


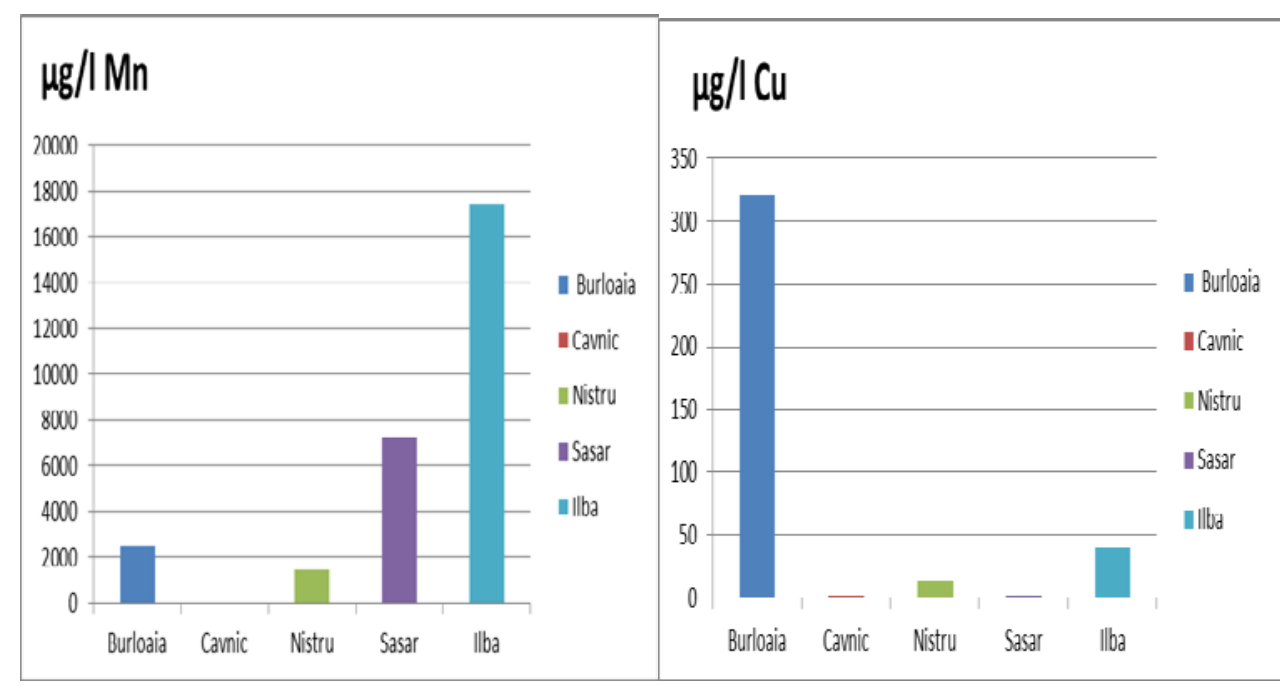

Fig.1. Mn concentration from rivers

Fig. 2. $\mathrm{Cu}$ concentration from rivers

The highest concentration of manganese is Ilba river, with a value of $17467.18 \mu \mathrm{g} / \mathrm{l}$. In Sasar river we have a $7289.96 \mu \mathrm{g} / \mathrm{l}$ of manganese concentration. The lowest concentration of manganese is in Cavnic river, with a value of 14.52 $\mu \mathrm{g} / \mathrm{l}$. The highest concentration of copper is Cisla river, with a value of $321.1 \mu \mathrm{g} / \mathrm{l}$. In Ilba river we have a $40.23 \mu \mathrm{g} / \mathrm{l}$ of copper concentration. The lowest concentration of copper is in Cavnic river, with a value of $2.38 \mu \mathrm{g} / \mathrm{l}$, and river Sasar $1.79 \mu \mathrm{g} / \mathrm{l}$.

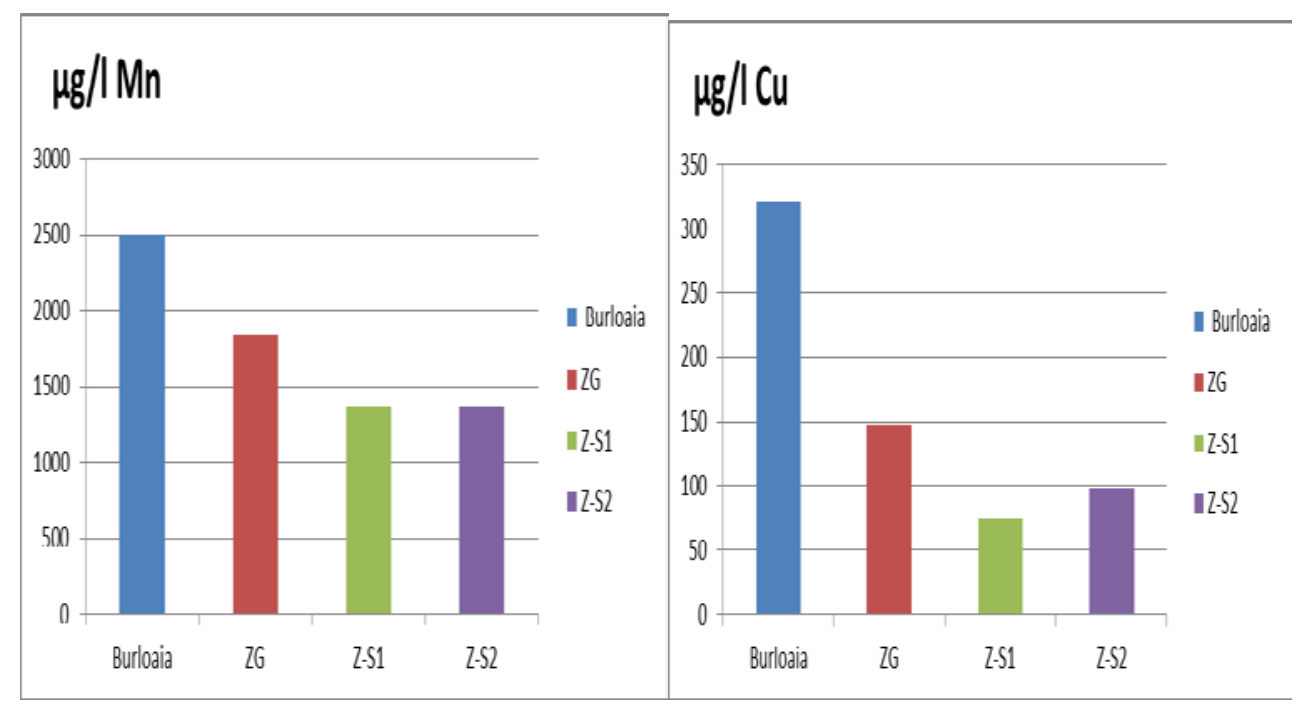

Fig. 3. Mn variation zeolites

Fig. 4. Cu variation zeolites 
The best manganase adsorbance is noticed for the grained zeolite Z-S1 and Z-S, produced by SC Zeolitos SRL followed by the green zeolite from Călineşti The variation of the copper concentration from Burloaia mine waters of Cisla river is presented in (Fig. 4).

The variation of manganese concentration from mine waters of Burloaia mine of Baia Borşa on various zeolites is presented in (Fig. 3).

The best copper adsorbance is noticed for the grained zeolite Z-S1 and ZS, produced by SC Zeolitos SRL followed by the green zeolite from Călineşti

The variation of the manganese concentration from Ilba mine waters of river is presented in (Fig. 5). The variation of the copper concentration from Ilba mine waters of river is presented in (Fig. 6)

The best manganase adsorbance is noticed for the grained zeolite Z-S1 and Z-S2, produced by SC Zeolitos SRL followed by the green zeolite from Călineşti.

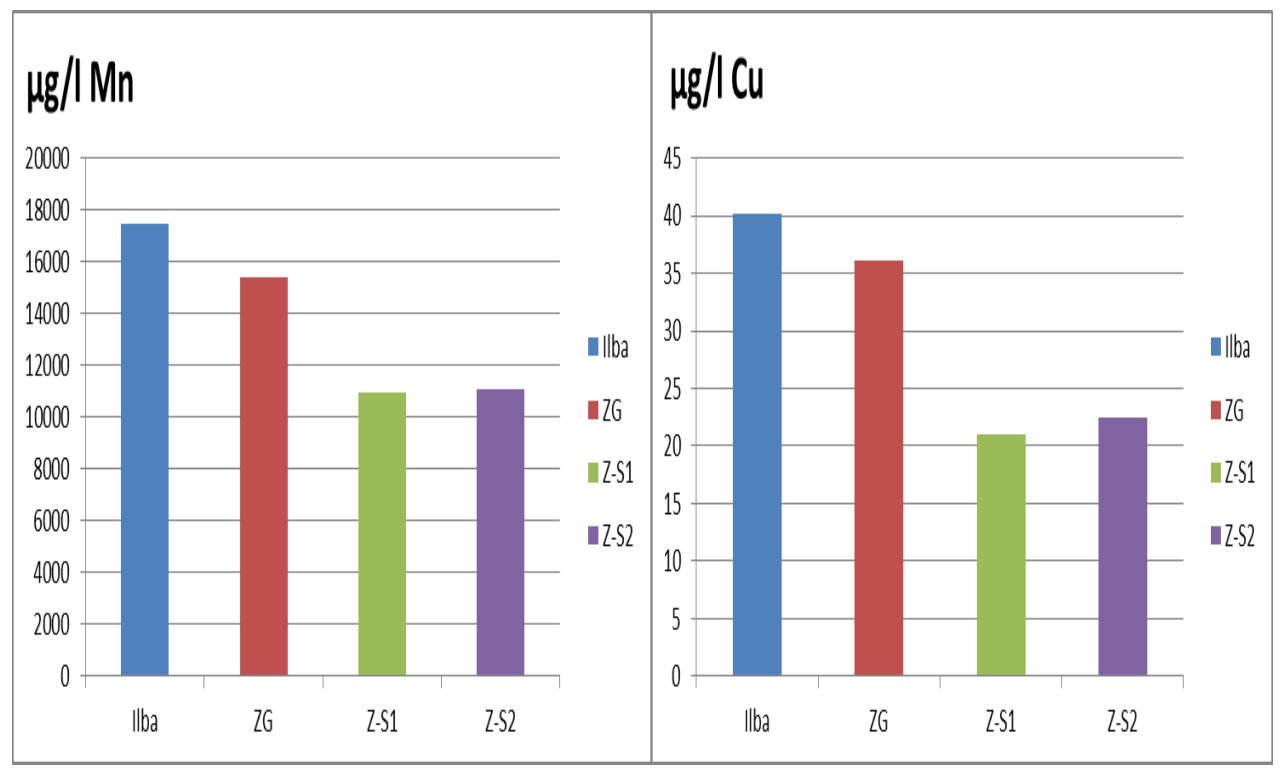

Fig. 5. Mn variation Ilba river

Fig. 6. Cu variation Ilba river

The best copper adsorbance is noticed for the grained zeolite Z-S1 and ZS, produced by SC Zeolitos SRL

The variation of manganese concentration from mine waters of Nistru river of Busag on various zeolites is presented in (Fig. 7).

The absortion of manganese in water of the river Ilba is almost identical for the three types of zeolites. The concentration of manganese in water decreases from $1499.4 \mu \mathrm{g} \mathrm{Mn} / \mathrm{l}$ to about $800 \mu \mathrm{g} / \mathrm{l}$.

The variation of manganese concentration from mine waters of Sasar river of Baia Mare on various zeolites is presented in (Fig. 8). 


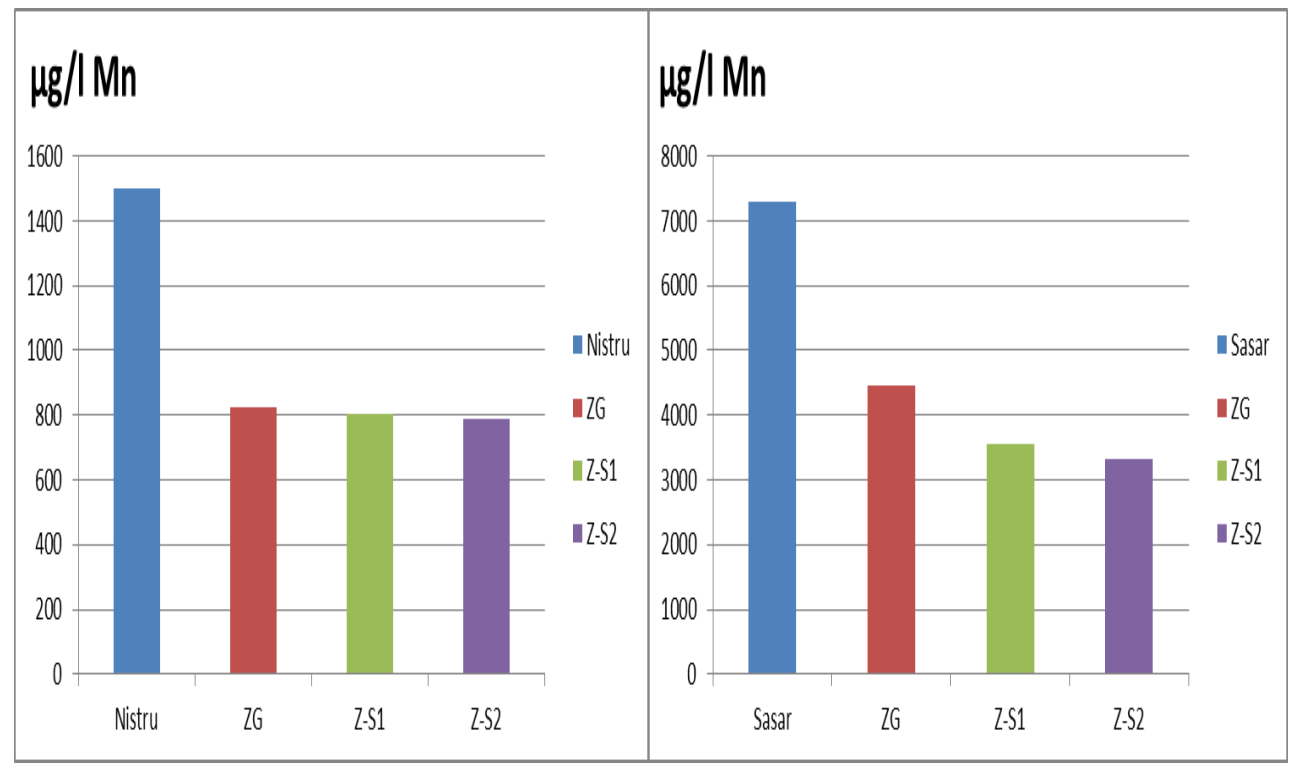

Fig. 7 Mn variation Nistru river

Fig. 8 Mn variation Sasar river

The absortion of manganese in water of the river Sasar is almost identical for the two types of zeolites Z-S1 and Z-S2.. The concentration of manganese in water decreases from $7289.96 \mu \mathrm{g} \mathrm{Mn} / \mathrm{l}$ to about $3400 \mu \mathrm{g} / \mathrm{l}$.

\section{CONCLUSIONS}

Natural zeolites are important low cost materials for water and wastewater treatment. The best results in the retention of the heavy metals in mining areas are obtained for the grained zeolites (Z-S1 and Z-S2) followed by the green zeolite (ZG) from Călineşti, Maramureş county.

Their exceptional physico-chemical properties (mechanical and thermal stabilities), the high efficiency to retain manganese, copper and iron ions and other metals, reccommends them as cheap and efficient solutions in developing technologies for waste water treatment and intervention to accidental pollution by mine waters on small rivers.

Further testing is necessary in order to establish practical technical protocols of usage and to prevent unwanted situations.

\section{ACKNOWLEDGMENTS}

We thank prof. dr. Luminiţa Silaghi-Dumitrescu from the Faculty of Chemistry and Chemical Engineering of the Babeş-Bolyai University for her generosity and professional support. 
We thank managers of the "Apele Române" National Administration, especially manager dr. Dragoş CAZAN; the managers of the Someş-Tisa Water Basin Administration for their support; to the Regional Laboratory for Water Quality Cluj, for the experiments and chemical analysis and to the Water Quality Laboratory Baia Mare for the water sampling.

We also thank managers of SC Zeolitos SRL Oradea and to the Călineşti townhall from Maramureş county, who provided the zeolite samples free of charge.

\section{REFERENCES}

1. E. M. Flanigen, R.W. Broach, S.T. Wilson, History zeolites; www.wileyvch.de./books/sample/3527325050_c.01.pdf

2. B.I. Mocanu, N. Naum, Cr. Lungu, D. Bambo, Mihaela Bambo, (2008), Particularităta compoziționale ale tufului vulcanic zeolitic de Piatra-Verde Slănic , Rev. Chim, 59, 17, 730-733, Bucharest.

3. A. Bărbat, A. Marton, (1989), Tufuri vulcanice zeolitice, Editura Dacia, 16-19, ClujNapoca

4. Mabel Vaca Mier, R.L. Callejas, R. Gehr, Blanca E. Jimenez Cisreros, P.J.J. Alvarez, ( 2001), Heavy metal removal with Mexican clinoptilolite multicomponent ionic exchange, Wat. Res.,35, 2 373-378; w.w.w.elsevier.com/locate/waters.

5. E. Erdem, N. Karapinar, R. Donat, (2004), The removal of heavy metal cations by natural zeolites, Journal of Colloid and Interface Science, 280,2, 309-314; http://doi.10.1016/j.jcis.2004.08.028

6. Maria K. Doula, (2009), Simultaneous removal of $\mathrm{Cu}, \mathrm{Mn}$, and $\mathrm{Zn}$ fromdrinking water with the use of clinoptilolite and its Fe-modified form, Water Research, XXX, 1-14; http://www.elsevier.com/locate/watres.

7. K. Kedziora, J. Piasek, J. Szerment, A. Ambroziwicz-Nita, (2014), Use of modified zeolite in environmental engieneering, http://www.zeolity.wszia.edu.pl./documents/2014/12

8. H.S. Abd.El-Gawad, (2014), Aquatic environmental monitoring and removal efficiency of detergents, Water Science, 28, 51-64: http://www.elsevier.com/locate/wsj.

9. R. Johnston, H. Heijnen, Safe Water Technology for Arsenic Removal, : http://www.archive.unu-ed/env/arsenic/Han.pdf

10. B.I. Mocanu, N.Naum, Cr. P.Lungu, O. Georgescu, Gh. Brănoiu, (2009), The immature crystallized substances influence concerning the features and proprietities of the volcanic zeolitic tuffs, Proc.Rom. Acad serie B, 1, 53-57:

11. S. Neagoe, O. Pântea, Eva Trâmbiţaşu, Daniela Popovici, D. Bomboş, Fănica Bacalum, Dorina Matei, C. Negoe, T. Jugănaru, M. Hoticeanu, (2004), Conditioning of zeolite store from Zalău physical-chemical studie, Analele Universităţii din Bucureşti-Chimie, XII, v I-II, 255-262

12. Irina Smical, L. Mihaly-Cozmuţa, D. Costea, (2010), Research concerning the influence of several factors on $\mathrm{Pb}^{2+}, \mathrm{Cu}^{2+}$ and $\mathrm{Zn}^{2+}$ ions adsorbtion bz natural zeolite tuff from Maramureş, county Northern Romania, AES Bioflux, v.2, 171180: http://www.aes.bioflux.com.ro 
13. T. Cătuneanu, Lucica Mircea, R. Vasiu, Fr. Gnandt, (2010), Reciclarea apelor uzate industrial cu conţinut de metale grele, prin schimb ionic, Conferinţa Ştiinţifică Sebeş 2010.

14. W. Mozgawa, Magdalena Krol, Katarzyna Barczyk, (2011), FT-IR studie of zeolites from different structural groups, Chemik, 7, 65, 671-674.: www. chemikinternational.com/pdf/2011/07_2011/chemik_2011_7_10pdf

15. F. Ruggieri, V. Marin, D. Gimeno, J.L. Fernandez-Turiel, M. Garcia-Valles, L. Gutierrez, (2008), Application of zeolitic volcanic rocks for arsenic removal from water, Engineering Geology, 101, 245-250

16. A. Yorukoglu, Influence of acid activation on the ion-exchange proprieties of Manisa-Gordes clinoptilolite, (2012), Physicochem. Probl. Miner. Process, 48(2), 591-598.

17. Elizabeth Von-Kiti, (2012), Syntesis of zeolites and their application to the desalination of seawater- Final Thesis, http://www.r.knust.edu.gh/bistream/123456789/4083/1

18. V.J. Inglezakis, K.J. Hadjandreou, M.D. Loizidou, H.P. Grigoropoulou, (2001), Pretreatment of natural clinoptilolite in a laboratory-scale ion exchange packed bed, Water Research, 35, 2161-2166.

19. Štefica Cerjan-Stefanovic', Lidija Curkovic', T. Filipan, (1996), Metal ion excange by natural zeolites, Croatica Chemica Acta, 69(1), 281-290:

20. S. Wang, Y. Peng, (2010), Natural zeolites as effecive adsorbents in water and wastewater treatment, Chem. Eng. J., 156(1), 11-24.

21. T.H. Eyde, Using zeolites in the recovery of heavy metals from mining effuents: http://www.gsaresourecs.com

22. A. Cincotti, N. Lai, R. Orru, G. Cao, (2001), Chem. Eng. J., 84(3), 275-282.

23. A.Z.Woinarski, I. Snape, G.W. Stevens, S.C. Stark, (2003), The effect of cold temperature on copper ion exchange by natural zeolite for use in a permeable reactive barrier in Antartica, Cold Regions Science and Technology, 137, 159168

24. www.zeolitos.ro/contact.html

25. *** SR EN ISO 17294-1: (2007), Calitatea apei , Aplicarea spectrometriei de masa cu plasma cuplata inductiv (ICP-MS), Partea 1, Linii directoare generale

26. *** SR EN ISO 17294-2: (2005), Calitatea apei, Aplicarea spectrometriei de masa cu plasma cuplata inductive(ICP-MS), Parte 2, Determinarea a 62 de elemente 